\title{
Correction: Enrichment of lung microbiome with supraglottic taxa is associated with increased pulmonary inflammation
}

Leopoldo N Segal ${ }^{1,2,3^{*}}$, Alexander V Alekseyenko ${ }^{3,4}$, Jose C Clemente ${ }^{5}$, Rohan Kulkarni ${ }^{2}$, Benjamin Wu², Zhan Gao ${ }^{3}$, Hao Chen ${ }^{4}$, Kenneth I Berger ${ }^{1,2,3}$, Roberta M Goldring ${ }^{1,2,3}$, William N Rom ${ }^{2,3}$, Martin J Blaser ${ }^{3}$ and Michael D Weiden ${ }^{2,3^{*}}$

\section{Correction}

After publication of this work [1], we noted that we inadvertently failed to include the complete list of all co-authors. The full list of authors has now been added and the Authors' Contributions and Competing Interests sections modified accordingly.

\section{Competing interests}

The authors declare that they have no competing interests.

\section{Authors' contributions}

Conception and design: LNS, MJB, MDW. Acquisition of data: LNS, RK, KIB, RMG, ZG. Analysis and interpretation of data: LNS, AVA, JCC, BW, HC, ZG, MJB, MDW. Drafting or revising of article: LNS, AVA, JCC, KIB, RMG, WNR, MJB, MDW. Final approval of the manuscript: LNS, AVA, JCC, MJB, MDW. All authors read and approved the final manuscript.

\begin{abstract}
Acknowledgements
This research was supported in part by grants: K24 Al080298; CTSI Grant \#UL1 TR000038; EDRN 5U01CA086137-13; Diane Belfer Program for Human Microbial Ecology; Michael Saperstein Scholarship Fund; R01DK090989; UH2 AR57506.
\end{abstract}

\begin{abstract}
Author details
'André Cournand Pulmonary Research Laboratory, Bellevue Hospital Center/ New York University School of Medicine, New York, NY, USA. ${ }^{2}$ Division of Pulmonary and Critical Care Medicine, New York University School of Medicine, New York, NY, USA. ${ }^{3}$ Department of Medicine, New York University School of Medicine, New York, NY, USA. ${ }^{4}$ Center for Health Informatics and Bioinformatics, New York University School of Medicine, New York, NY, USA. ${ }^{5}$ Division of Genetics and Genomic Sciences, Mount Sinai School of Medicine, New York, NY, USA.
\end{abstract}

Received: 23 June 2014 Accepted: 23 June 2014 Published: 2 July 2014

\footnotetext{
* Correspondence: Leopoldo.Segal@nyumc.org; Michael.Weiden@nyumc.org 'André Cournand Pulmonary Research Laboratory, Bellevue Hospital Center/ New York University School of Medicine, New York, NY, USA

${ }^{2}$ Division of Pulmonary and Critical Care Medicine, New York University School of Medicine, New York, NY, USA
}

\section{Reference}

1. Segal LN, Alekseyenko AV, Clemente JC, Kulkarni R, Wu B, Chen H, Berger Kl, Goldring RM, Rom WN, Blaser MJ, Weiden MD: Enrichment of lung microbiome with supraglottic taxa is associated with increased pulmonary inflammation. Microbiome 2013, 1:19.

\section{doi:10.1186/2049-2618-2-21}

Cite this article as: Segal et al:: Correction: Enrichment of lung microbiome with supraglottic taxa is associated with increased pulmonary inflammation. Microbiome 2014 2:21.

\section{Submit your next manuscript to BioMed Central and take full advantage of:}

- Convenient online submission

- Thorough peer review

- No space constraints or color figure charges

- Immediate publication on acceptance

- Inclusion in PubMed, CAS, Scopus and Google Scholar

- Research which is freely available for redistribution

Submit your manuscript at www.biomedcentral.com/submit
C) Biomed Central

\section{() Biomed Central}

(c) 2014 Segal et al.; licensee BioMed Central Ltd. This is an Open Access article distributed under the terms of the Creative Commons Attribution License (http://creativecommons.org/licenses/by/4.0), which permits unrestricted use, distribution, and reproduction in any medium, provided the original work is properly credited. The Creative Commons Public Domain Dedication waiver (http://creativecommons.org/publicdomain/zero/1.0/) applies to the data made available in this article, unless otherwise stated. 